\title{
A Letter From The New Minister
}

Ms. Yvette Knott

President, The Standing Conference of Canadian

Organizations Concerned for Refugees

Dear Ms. Knott:

Thank you for your letter of July 12, 1984, addressed to my predecessor, in which you provided a summary of the concerns expressed by members of the Standing Conference at your meeting in Montreal. I welcome this opportunity for an exchange of views on these important matters.

\section{A. SPECIAL AREA CONCERNS \\ Guyana}

I note your strong interest in the situation in Guyana, and I can assure you that my Commission is maintaining a close watch on developments in that country. As you may be aware, we have recently established a full-time immigration facility in Georgetown and have thus improved our ability to monitor the human rights situation in Guyana. It remains difficult, however, to identify a specific category of individuals whose position would justify special immigration measures. Such measures respond to conditions of oppression or forced displacement which fall within the UN definition of refugee status. While this may well be the case for some Guyanese, it is not a general condition; I do not consider, therefore, that special measures are warranted at this time.

\section{Guatemala}

The refugee situation in Central America continues to be a major preoccupation of my Commission. I am aware that the visa requirement for Guatemala has aroused particular concern among your members. I cannot agree, however, that the influx of refugee claimants from Guatemala was "insignificant" before the imposition of the visa requirement. In any event, the special program for Guatemala which was introduced in March of this year has produced welcome results in that the processing of 367 cases (involving 575 persons) was begun between March 15 and August 31, 1984. The new immigration facility in Guatemala City, moreover, has played an increasingly active role in assisting those persons who have shown an urgent need for resettlement in Canada.

The funding for ISAP Agencies has been increased by $12 \%$ from $\$ 3.1$ million to $\$ 3.6$ million.
Sri Lanka

The recent outbreaks of inter-communal violence in Lanka have reinforced our concern for the situation the Tamil community in that country. The roundtat discussions between the Tamils and Sinhalese are cos tinuing, however, and there is still some hope that compromise acceptable to both sides will eventur emerge. A full review of the Sri Lankan special measu is currently under way, and the question of land Tamil refugee claimants in Canada will be among issues given full consideration. In the meantime, the isting special measures (including the moratorium removals to Sri Lanka) will remain in force in their p sent form until the review has been completed.

\section{B. REFUGEE LEVELS}

I am gratified to learn that both guest speakers on opening night of the consultation praised Canada's p formance in refugee affairs. As you may be aware, 1983 level of government-sponsored refugee admissio was $90 \%$ filled (compared to $94 \%$ in 1982). Our foc on non-traditional sources in Africa, Latin Americ and the Middle East produced mixed results: in Afrte we fell short of our target, but the intake of 651 person was triple the number admitted in 1982; we were le successful in the Middle East, but our program in th area is steadily gaining momentum; in Latin America exceeded our target of 2,000 persons by over $10 \%$, addition, there was a shortfall in the Eastern Europe program because several hundred persons who appit to settle in Canada had also applied to other resett. ment countries and did not make use of the Canadif visas that were made available to them.

It must also be remembered that there are special logit: cal problems in operating a refugee program which truly global in scope, and in which we often cooper" with third parties - such as the UNHCR and chus: groups - in locating and interviewing those perse who are in need of resettlement. Although the tar: level may not be met in some years and in some plac. the strength of Canada's commitment to refugee reset ment cannot be doubted.

With respect to your suggestion that the allocation government-sponsored refugees from Hong $\mathrm{Kg}$ should be revised upwards, I am pleased to report 100 places were transferred from the regional reserve Hong Kong last spring. This number was supplemen by an additional 500 in July, making for a total of places. The question of an increased need for places the refugee allocation for Latin America will be tal into account in the formulation of the Annual Refu. Plan for 1985. We are also supporting efforts to invo. more countries in resettlement activities from this af Australia has recently established a regional office 
Central America, and has begun an active selection program. With respect to Southeast Asia, our Family Reunification Program has assisted an increasing number of persons to emigrate directly from Vietnam to Canda, thereby helping to reduce the refugee caseload in neighbouring countries.

Work Permits for Refugees as of December 3rd will no longer be tied to a specific job.

\section{SETTLEMENT CONCERNS}

\section{Integration of Central American Refugees}

I can assure you that my Commission is aware of the problems faced by Central American refugees in adapting to their new lives in Canada, and my officials are sensitive to the importance of landing these persons and completing the reunification of their families as soon as possible. With respect to employment authorizations for refugee claimants, my Commission has recommended revisions to the relevant regulations which should simplify the administration of this system. I expect to submit these amendments shortly to the Governor-in-Council; upon their approval, the revised regulations will come into effect.

\section{Handicapped Refugees}

I share your concern for handicapped refugees in need of resettlement. Many handicapped refugees have already been resettled through the normal movement to Canada, but have not been counted as "handicapped" in our statistics. Nevertheless, my officials are aware of the need to streamline the existing system, and new procedures and objectives for this program will be proposed to the provinces and other interested parties late this year. Your suggestion of a separate level for handicapped refugees has received serious consideration, and has been included in the new objectives for the program.

\section{Immigration Settlement and Adaptation Program}

I am pleased to learn that the Standing Conference has expressed its support of the new funding guidelines for ISAP, and my officials will continue to cooperate closely with voluntary agencies in the implementation of these guidelines. We continue, moreover, to be most conscious of the need to provide refugees with effective language training. Federal budget restraints, however, will limit our response to this need in the upcoming fiscal year.

Refugee Determination Procedures

In May, 1984, Cabinet approved a series of initiatives which were designed to secure improvements to the existing refugee determination system in Canada. The appointment of Rabbi Plaut to conduct a study of this system was one of these measures. As part of his mandate, Rabbi Plaut has undertaken to propose chances to the claims system which would best serve the competing objectives of fairness and efficiency. Rabbi Plaut is expected to issue his preliminary report by the end of 1984, and changes to the claims system will most likely be implemented over the next two or three years.

To this end, the Rabbi has recently completed a series of consultations with interested groups across Canada. Rabbi Plaut's mandate, moreover, includes consultations with officials of other governments, the United Nations High Commissioner for Refugees, and nongovernmental organizations outside Canada. Accordingly, Rabbi Plaut recently met with officials in Washington, D.C., and he will shortly visit France, Switzerland, and the Federal Republic of Germany in order to complete his study of Refugee determination procedures in other countries.

I can assure you that Rabbi Plaut has our full support in his effort to devise a more equitable and effective refugee determination system. We are cooperating closely with his study, and will be most interested in the results of his deliberations. In the meantime, the pilot project for oral hearings in Toronto and Montreal is still in effect.

Bond Requirements and Medical Services

I am pleased to note that your members supported the announcement of new procedures to ensure medical examinations for all refugee claimants. I have also noted your willingness to participate in the 1984-1985 national survey on the issue of bond requirements.

\section{Sponsorship/Resettlement Models}

The suggestion of a national consultation on sponsorship models - whether in the form of one national meeting or a series of regional and local sessions - has considerable merit. The latter option would appear to be preferably, since services to meet the settlement needs of new arrivals are generally provided by local groups, and techniques applicable in one part of the country would not necessarily prove successful elsewhere in Canada.

I wish to thank you again for forwarding the concerns which were expressed by the Standing Conference in Montreal, and I trust that the responses which I have provided will be of assistance to you. I look forward to continued cooperation with your members in maintaining Canada's traditional position of leadership in refugee resettlement efforts throughout the world.

Your sincerely,

Flora MacDonald 